\title{
Dealing with Unexpected Circumstances: Judicial Modification of Contract under Indonesian and Dutch Law
}

\author{
Taufiq Adiyanto \\ Faculty of Law, Universitas Gadjah Mada, Indonesia. \\ E-mail: taufiq.adiyanto@ugm.ac.id
}

\begin{tabular}{l} 
ARTICLE INFO \\
\hline Keywords: \\
Contract Law; Change of \\
Circumstances; Judicial \\
Modification \\
How to cite: \\
Adiyanto, T. (2019). \\
"Dealing with Unexpected \\
Circumstances: Judicial \\
Modification of Contract \\
under Indonesian and Dutch \\
Law," Hasanuddin Law \\
Review, 5(1): 102-119 \\
DoI: \\
10.20956/halrev.v5i1.1508 \\
\hline
\end{tabular}

\begin{abstract}
After the conclusion of a contract, uncontrolled situations of the parties may lead to non-performance of the contract not only in the form of impossibility but also through excessive onerousness. This paper is seeking to compare regulations and cases concerning change of circumstances of the contract under the Indonesian and Dutch legal systems. The aim is to compare a legal remedy when the contract is imbalance and puts other party in burdensome condition to perform. Indonesian law still uses the all-or-nothing approach of termination and rejects the concept of subjective (relative) force majeure to modify a binding contract, although in some cases Indonesian Supreme Court has modified some contracts on the basis good faith principle. Dutch law, on the other hand, has an explicit provision for adjustment of contract on the basis unforeseen circumstances in Article 6:258 DCC. This jurisdiction accepts that unforeseen circumstances can be justified as a basis for adaptation of the contract.
\end{abstract}

Copyright (C) 2019 HALREV. All rights reserved.

\section{Introduction}

A contract is a legally enforceable agreement - a bargain between multiple parties - to which each party has given their assent on the basis of circumstances agreed at the time of the contract. The parties initially have to assess many possibilities and risks that can happen before concluding the contract. Once the parties have reached a consensus, in adherence to the principle of pacta sunt servanda (Latin for 'agreements must be kept'), the contract is binding and therefore enforceable among them. They are obliged to obey each clause that has been agreed in the contract under the circumstances prevailing at the time when executing the contract.

However, after concluding the contract, especially a long-term contract, many things can happen. Even after parties have already foreseen the entire performance of the contract, supervening circumstances surrounding the contract can go beyond reasonable expectation and may raise serious doubts about the binding nature of the contract, which 
can eventually hamper the performance of the contract. In the case of interruption, the doctrine of pacta sunt servanda will be challenged by doctrine of rebus sic stantibus. On the one hand, pacta sunt servanda means that the involved parties are bound by their agreement and this tends to require the performance of the contract, even it is impossible to perform. A party cannot escape from liability due to miscalculation of risk in the future. ${ }^{1}$ On the other hand, rebus sic stantibus means that the binding force of a contract is directed at to the implied condition that the state of affairs present at the time of its conclusion should continue unchanged. ${ }^{2}$ It is obvious that the rebus sic stantibus principle opposes the pacta sunt servanda principle, since the contracting parties still have room to deviate from their respective original contractual obligations in certain circumstances.

Such situations as lie outside the control of the parties may lead to (1) non-performance in the form of impossibility or (2) (only) a higher level of burden for one of the parties to carry out their contractual performance. In the case of impossibility to perform, the situations usually include conditions in which the delivered goods are damaged, or when there are occurrences of hurricane, flood, and earthquake. Other than that, nonperformance of the contract may be caused by a difficulty to perform due to burdensome conditions (e.g. hardship). ${ }^{3}$ These conditions may include, for example, a revolution in technology, isolation of specific markets due to safety reasons or caused by a new regulation that prohibits delivery of the goods. Such hindrances may also take the form of a relentless inflation or a crisis in the currency exchange market.

Theoretically, impossibility refers to the condition whereby the performance is prevented by a factual or legal obstacle. Hence, the debtor cannot overcome the problem by conducting a particular action or effort. Furthermore, on the condition of impossibility, the obligation no longer exists because the debtor is released from contractual liability unless there was a negligence (negligentia, culpa) caused by himself. In contrast, a change of circumstances under conditions of excessive onerousness shows that the obstacle does not create impossibility of the performance. The obligation remains the same, but there is a fundamental alteration in the circumstances surrounding the contract, which leads to a performance that is much more burdensome to a disadvantaged party.

The second type of non-performance mentioned above will be discussed further in this article. However, before examining this topic in greater depth, a problem of the uniformity of legal terms needs to be addressed. It has been accepted that each legal system may use different terms for the generic expression "change of circumstances". Indonesian law refers to the concept as a "relative (subjective) force majeure", the Dutch law applies the term "unforeseen circumstances", In international contract law, the common term is "hardship", but nevertheless during the last few years, the phrase "change of circumstances" has become most commonly used.

Pursuant to deviation from the original contract, legal systems around the world have different approaches in observing the occurrence of a change of circumstances, and of determining whether it is fair, reasonable, and legal to hold parties strictly accountable to their original contract. The question in turn revolves around the possibility of revising

1 Hondius, E., \& Grigoleit, H. (2011). Unexpected Circumstances in European Contract Law. Cambridge: Cambridge University Press, p. 3-4

2 Momberg Uribe, R. (2011). The effect of a change of circumstances on the binding force of contracts: Comparative perspectives (Ius Commune reeks; 94 114765189). Cambridge: Intersentia, p. 6

3 Horn, N. (1985). Adaptation and renegotiation of contracts in international trade and finance (Studies in transnational economic law; vol. 3. 821849247). Deventer: Kluwer Law and Taxation, p. 16 
a contract by the court on the ground of the change of circumstances. This article will be aimed to observing the perspectives of two closely-related civil legal systems, which are Indonesian law and Dutch law. In addition, it is important to bear in mind that the analysis of Indonesian and Dutch law in this article is intended to refer a contract that has no explicit clause of change of circumstances. This may be caused by the parties' choice not to agree on such a clause being mentioned in the contract.

\section{Change of Circumstances as a Basis for Contract Modification in Indonesian Law}

This section discusses the origin and development of the force majeure rules in Indonesian contract law. In the development of the rules, the judicial approach moved from strict implementation of force majeure to subjective (relative) force majeure. The last part of this section will discuss relative (subjective) force majeure as a ground for contract modification.

\subsection{Change of Circumstances under Indonesian Law}

The Indonesian law of obligations is regulated under the Indonesian Civil Code (ICC). The ICC, or Burgerlijk Wetboek voor Indonesie, is the translation of old Dutch Burgelijk Wetboek, which was previously adapted from the French Civil Code prior to its reformation. ${ }^{4}$ The Indonesian Civil Code upholds the sanctity of contract in the same way as does the old Dutch Contract Law. Both instruments have a similar attitude towards a contractual relationship since the Indonesian Civil Code is derived from the old Dutch Civil Code of the Netherlands during the colonial era. ${ }^{5}$

The recognition of the sanctity of contract is expressed when parties are primarily bound by the pacta sunt servanda principle after they concluded a contract. The notion of the sanctity of contract also protects freedom in determining contractual terms (party autonomy). The application of contractual terms must be respected and ensured by the court. This means also any other interference to the contract on may be regarded as a source of uncertainty and unpredictability. The idea is clearly stated in Article 1338 ICC in the following way: ${ }^{6}$

a. All valid agreements apply to the individuals who have concluded them as law.

$b$. Such agreements are irrevocable other than by mutual consent, or pursuant to reasons stipulated by the law.

c. They must be executed in good faith.

Occasionally contract cannot be carried out because of non-performance of the contractual term. The Indonesian Civil Code distinguished non-performance of contract between culpable (actionable breach) and non-culpable non-performance (impossibility due to force majeure). Breach of contract authorised the creditor to claim the court for

4 After the New Dutch Civil Code was enacted in 1992, Dutch contract law has adopted a very different approach in change of circumstances. This will be discussed in the Dutch law section.

5 The Indonesian Civil Code was derived from Roman Civil Law. In 1804, Napoleon compiled a set of rules, namely the Code Civil des François or Code Napoleon. It was used by the Netherlands and subsequently Indonesia adopted it up until the present day. The old Dutch Civil Code was enacted in Indonesia by Staatsblad on 30 April 1847 No. 23. Since the declaration of independence of the Republic of Indonesia, it remains in effect under the Transitional Rules of Article II of Constitution of the Republic of Indonesia 1945. See Soerodjo, I., (2016). the Development of Indonesian Civil Law, Scientific Research Journal (SCIRJ), IV (IX): 1

6 All Articles of the ICC are cited from Indonesian Civil Code from the translation of Rahmanata, A., \& Wirana, A. (2009). Civil code for Indonesia : Burgelijk wetboek, proclaimed by the publication of April 301847 S. No. 23. Jakarta: Lembaga Penerbit Fakultas Ekonomi Universitas Indonesia. 
termination and damages. By contrast, force majeure stopped the contract and discharged both parties from any duty to perform. In the ICC, force majeure concerning compensation is regulated under Articles 1244 and 1245, which read as follows:

Article 1244 ICC:

If there is any reason for such, the debtor shall compensate for costs, damages and interests if he cannot prove, that the non-performance or the late performance of such obligation, is caused by an unforeseen event, for which he is not responsible, and he was not acting in bad faith.

Article 1245 ICC:

No compensation of cost, lost and interest, if the debtor because of an act of God or an accident was prevented from giving or doing an obligation, for which he was obliged to do or had done something, which he was forbidden.

In addition to Articles 1244-1245 ICC, the concept of force majeure in the context of duty to deliver a particular object is also referred to in Article 1444 ICC. According to the Article, an obligation to deliver a particular object, such as in a sales and purchase contract, was deemed to be extinguished if the object was destroyed due to a nonculpable cause.

Pursuant to the Articles cited above, we can identify that there are at least three elements for force majeure, namely (1) the existence of unforeseen events, (2) the risk that cannot be accounted to the debtor, and (3) the good faith of the debtor. These three criteria shall all be fulfilled for a successful force majeure defence. In light of these requirements, it can be observed that force majeure refers to a performance that has become undeniably impossible because of an unforeseeable event that is not imputable to the debtor. The party who was responsible for the non-performance is required to notify the other party about the obstacles and its impact on the possibility of performing the contractual terms. This is because the debtor shall act in accordance with the third criterion, the principle of good faith.

It is notable, in Indonesian contract law, the concepts of force majeure in Articles 1244, 1245 and 1444 of the ICC were interlinked, and commonly named as an all-or-nothing approach. This means if performance was entirely impossible due to a cause for which the debtor had no responsibility towards the obligation, the contractual obligation was terminated immediately. If, however, performance was fully possible, there was no force majeure. The judge generally put impossibility test to decide whether the circumstance was categorized as a force majeure rather than test on the limits of culpability or imputability of risk.

When dealing with the external cause which hampers the performance of a contract, Indonesian law at the present moment only has a solution under the principle of force majeure (1244, 1245 and 1444 ICC). Indonesian contract law does not have any explicit provisions which stipulate the change of circumstances particularly that do not amount to impossibility. The invocation of unexpected circumstances, aside from impossibility, to a binding contract, is not acceptable under ICC unless there is an impossibility to perform. In other words, a party cannot be released from any obligations when the performance has become excessively burdensome.

Knowing that ICC had been influenced by old Dutch Civil Code and original French Civil Code 1804, it is little surprise that the provisions mentioned above also share the same ideas with the old DCC and the original French Civil Code. With respect to the concept of force majeure, Article 1244-1245 ICC are comparable with Articles 1280-1281 
the old DCC and Articles 1147-1148 of the original FCC. These Articles are key provisions in addressing the event of force majeure when performing a contract in those Codes. It is stated that, indeed, the French Civil Code position in 1804 did not acknowledge the doctrine of imprevision 7 as a basis on which to modify a contract. Instead, it had a strong acknowledgement of the pacta sunt servanda principle which was stipulated in Article 1134 of the original French Civil Code. 8 Therefore, it makes sense that a similar standpoint was also reflected in the old Dutch Civil Code and the Indonesian Civil Code, neither of which explicitly accommodated the change of circumstances other than impossibility in the Civil Codes. The fundamental idea of the liberal doctrine on which the French Civil Code was established, complete with its formulation of individual liberty, seems to be one key reason that the French Civil Code had such a standpoint.

The strict implementation of force majeure can be seen in the following cases. In the case of NV Handel Maatschappij L'Auto v. G.G. Jordan, a car was an object of a hire-purchase contract between the NV Handel Maatschappij L'Auto (a car shop) and Jordan. NV Handel Maatschappij L'Auto sued Jordan to pay off the lack of installments on the car. Jordan argued the car was seized by the Japanese armies when they landed in Java on October 1944, and he had no need to pay the remaining installments because the car could be considered destroyed. However, the Supreme Court held that the situation was not deemed to be a force majeure under the ICC. Hence Jordan had to compensate the loss to the car shop. ${ }^{9}$ This was also so in the R.P. Adianto Notonindito v. PT Tirta Santika case. In this example, the plaintiff signed the Ship Rental (Charter Partij) Agreement with the defendant. The defendant claimed that it was a case of force majeure because he could not carry out his performance but the Supreme Court held that the instruction of the administrative authority which postponed the obligation was not deemed to be a force majeure under the ICC, and therefore, it ruled in favour of the Adianto Notonindito. 10

Within the space of several decades, the discourse of strict and narrow implementation slowly shifted to an open and broader interpretation of the force majeure doctrine. The cases in the previous discussion illustrate the way that the courts previously insisted on implementing a narrow interpretation of the concept of force majeure with the all-ornothing solution under the ICC, in which if the performance was impossible, the contractual obligation was dismissed, and if the performance was entirely possible, there was no force majeure.

During development of the doctrine, the courts have made a breakthrough in interpreting force majeure in the fulfilment of a contract in a broader sense. The courts mentioned subjective or relative force majeure as an alternative solution to justify the event of force majeure which does not amount to impossibility. A relevant case in which Supreme Court held that a relative force majeure exists is stated in the decision of the Indonesian Supreme Court 1787K/PDT/2005. This case was related to a performance of Build-Operate-Transfer (BOT) Contract of Pertamina Gas Tower between PT. Pertamina

7 The French legal system has been reluctant to recognise the influences of change of circumstances on a binding contract, and this situation is addressed in French law under théorie de l'imprévision or doctrine of imprevision. The term Imprevision in French legal system is comparable to the term change of circumstance. For further information, see Momberg Uribe, R., op.cit., 43.

8 Articles are cited from the original French Civil Code from the translation of Prof. Georges Rouhette, Professor of Law, with the assistance of Dr Anne Rouhette-Berton, Assistant Professor of English.

9 The Decision of Indonesian Supreme Court No.15 K/Sip./1957 (NV Handel Maatschappij L'Auto v. G.G. Jordan).

10 The Decision of Indonesian Supreme Court No. 3389 K/PDT/1984 (R.P. Adianto Notonindito v. PT Tirta Santika). 
(Persero) and PT. Wahana Seno Utama. ${ }^{11}$ Initially, this agreement appeared to be in good condition, but in 1997 the agreement was disrupted because of the economic crisis that happened in Indonesia. Prices went soaring upwards uncontrollably, and this caused PT. Wahana Seno Utama as the defendant to suffer from difficulties in performing its obligation. According to the Supreme Court decision, the judges upheld the District Court and ruled that the circumstances (monetary crisis) were a generally accepted condition in society, and constituted a valid reason that could hamper the construction of a building such as Pertamina Gas Tower. The judges insisted that economic changes in the form of a world economic recession can be classified as a force majeure event.

The wider view of the implementation of force majeure has therefore been confirmed by many legal scholars since 1950. Many Indonesian legal experts have since attempted to promote the change of circumstances in the sense of a relative force majeure from time to time. There are at least three different generations of Indonesian jurists who determined the meaning of force majeure to be other than impossibility, each of which can be taken in turn. Firstly, Kusumadi, a senior legal scholar in Indonesia, categorised force majeure under a twofold system in 1950, namely by distinguishing between objective force majeure and subjective force majeure. 12 Objective force majeure refers to the impossibility to perform, and subjective force majeure refers to difficulties (non-impossibility). The latter has a similar function with regard to a change of circumstances. Subsequent to this, another senior Indonesian jurist, Soebekti, also acknowledged that there is another form of force majeure as well as impossibility. ${ }^{13}$

Secondly, in 1970, Sri Soedewi Masjchun Sofwan provided a definition of force majeure which not only included a state in which it is impossible for the debtor to perform. She then called it a case of absolute force majeure. In contrast with this absolute type, if the application requires a great sacrifice which lies outside the bounds of human capability and causes enormous losses, it is classified as relative force majeure. ${ }^{14}$ Thirdly, in 1990 Yahya Harahap and J. Satrio expressed similar frameworks on force majeure. They mentioned two kinds of force majeure, namely absolute (objective) and relative (subjective) force majeure. The relative force majeure prevails in the form of a condition in which the agreement can still be implemented, but at a significant disadvantage on the part of the debtor, for example when the price of goods soars too high, or when there is a prohibition on sending goods imposed by the Government. ${ }^{15}$ Rosa Agustina also admitted this latter conception of relative force majeure in her book. ${ }^{16}$

\subsection{Judicial Modification under Indonesian Law}

In the Indonesian Civil Code (ICC), which was enacted nearly seventy years ago, the court is not equipped with the power to modify a binding contract. The main role of a court under the ICC is to ensure the performance of a contract and to decide whether a certain juridical consequence shall or shall not occur in light of the force majeure. As was

11 The Decision of Indonesian Supreme Court No. 1787 K / PDT / 2005 (PT. Pertamina (Persero) v. PT. Wahana Seno Utama).

12 Soemadipradja, R. (2010). Penjelasan hukum tentang keadaan memaksa. Jakarta: Nasional Legal Reform Program (NLRP), p. 32

13 Soebekti, R. (2002). Hukum perjanjian (Cet.ke-19. ed.). Jakarta: Intermasa,p. 56

14 Sofwan, S. (1980). Hukum perutangan. Yogyakarta: Seksi Hukum Perdata Fakultas Hukum, Universitas Gadjah Mada, p. 20

15 Soemadipradja, R. op.cit. 36.

16 Agustina, R, Suharnoko \& Nieuwenhuis, H. (2012). Hukum perikatan (Law of obligations) (Seri unsurunsur penyusun bangunan negara hukum. Denpasar: Pustaka Larasan, p. 6 
discussed above, the ambit of force majeure has become relatively wider due to the increasingly prevalent concept of subjective (relative) force majeure, but regrettably, the primary remedy for a change of circumstances remains the same under Article 1244 and 1245 of the ICC. Hence, when a force majeure occurs in a binding contract, a party who cannot perform the contract, cannot be stated as a defaulting party, and the contract will be discharged. This occurrence of force majeure will release the debtor of his obligation to repair the damage caused by a failure in the performance. This termination effect also applies in the event of relative force majeure.

However, some Indonesian jurists did mention the possibility of adapting contractual clauses that correspond to the new legal environment, which is burdensome to one party but which has been adopted by some jurisdictions in Europe such as the Netherlands and France. They argued that even though parties are bound to the pacta sunt servanda principle contained in Article 1338 Paragraph 1 of the ICC, they are also bound by Article 1339 of the ICC. The Article states that "agreements bind the parties not only to that which is expressly stipulated, but also to that which, under the nature of the agreements, shall be imposed by propriety, customs, or the law." The Article implies that contractual provisions that are agreed by parties in the contract are supplemented as needed by statute, custom and law. The law in this Article also refers to Article 1338 Paragraph 3, which stipulates good faith principle on the performance of the contract. According to Sudargo Gautama, the standard of good faith is invoked if only there is no statutory provision or custom to settle a certain case. ${ }^{17}$ In the event that statute and custom are opposed, the statute takes priority unless it is also customary to include the customary provision in the contract itself. ${ }^{18}$

Based on the aforementioned provisions, one may argue that in order to ensure the enforcement of good faith in a contractual relation the judges also have the authority to supervise the implementation of the contract and to invoke the principle of good faith. ${ }^{19}$ The good faith principle is not merely related to the construction of the agreed contractual obligations. It could also serve as a normative principle that shapes the content of a contract. This good faith principle can serve as a legal ground for judges to determine the relative force majeure and the possibility of a contract modification to keep implementation and to restore the stability of the contract.

A thorough understanding of the implementation of the good faith principle is apparently seen in the mind of Indonesian jurists and the Indonesian Supreme Court in May 1955. Based on the good faith principle in Article 1338 ICC, the Supreme Court gave consideration of the land price before the war at the worth of Rp. 50,- (fifty rupiahs), but the Supreme Court did not accept the fact that a land which had been encumbered with a mortgage for Rp. 50,- prior to World War II was to be redeemed at the same price. The Court instead fashioned its formula of redemption in light of the good faith principle, insofar as it noticed that the value of gold had gone up 30 times during the intervening years. The judges then said that "it is required that the risk of currency fluctuation shall be born equally by the parties even though the contract fixed the price of redemption at Rp. 50,-". As a result, the judges held that the plaintiff could pay 50 per cent of $30 \times \mathrm{Rp}$.

17 Gautama, S. (1995). Indonesian business law (Cet. ke-1.. ed.). Bandung: Citra Aditya Bakti, p. 84.

18 For example, it is customary but at the same time not a customary provision in a rental contract for a lessor to collect his rent at the premises of the lessee. In contrast, Art. 1393 of the ICC stated that the debtor is bound to make a payment at the premises of the creditor. If no such location has been stipulated, payments concerning predetermined goods take place where the goods were located at the conclusion of the agreement. On this reasoning, the lessee must make payment at the place of the lessor.

19 Gautama, S. op.cit. 85. 
50,- i.e. Rp. 750,-. Although this case also involved adat law, 20 it illustrates that the court can intervene and adjust the contractual terms, in which such an intervention is made in the context of the good faith implementation in Article 1338 of the ICC. Following this, the Decision No. 3703 K / Pdt / 1986, the Supreme Court determined that changes to the value of the currency should be charged to both parties in proportion to the price of gold as the standard. However, in this case, the Supreme Court did not explain why it had come to this conclusion. There was no legal consideration that led to such a conclusion. The Supreme Court merely said that it must follow the existing jurisprudence. In the decision of the Supreme Court No. 983 K/PDT/1991 on 26 September 1996, the case Haryo v. Bank Pasar Dwimanda, the judges also showed the possibility of adjusting the contractual provisions based on Article 1338 of the ICC. They held that Haryo as the debtor in the contract was in the burdensome situation. Therefore, the interest of payment was adjusted from 39.6 per cent per annum to 15 per cent per annum.

Given the reasoning of the decision mentioned above, we can indeed recognise some changed circumstances cases that have explicitly shown that the judges might revise a binding contract on the foundation of good faith. Even so, the solution of the above quandary does not provide a lasting answer in dealing with subjective (relative) force majeure events. It is important to note that Indonesia does not embrace a system of judicial precedent. As a consequence of this fundamental tenet, the judges possess extensive discretion in settling a dispute without being bound by previous judgments as long as they lie within the corridor of legislation. Furthermore, even though there was a precedent in contractual adaptation, it is still uncertain whether the other judges would decide in the same manner. In recent years, civil courts in Indonesia have tried to implement a broader interpretation of force majeure and good faith performance. Nevertheless, the remedy for the narrow interpretation of force majeure which leads to the termination of a contract remains the majority view that prevails on a default basis. Neither of the parties is allowed to ask the courts to revise the contract.

Following the explanation set out in the above paragraph, I argue that the demand of explicit provisions which give room for contractual modification is necessary, especially in a situation that causes burdens to a party in the Indonesian legal system. There should be some exception of the strict implementation of pacta sunt servanda principle in Indonesian contract law. As stated by Kotter, the greatest challenge of business today is how to remain competitive amidst continuous economic turbulence and disruption. ${ }^{21}$ Commercial contracts demand the possibility of adjustment in the case of a severe imbalance between the rights and obligations of all involved parties. The strict performance of pacta sunt servanda may lead to an unjust result that is against the notion of justice. Moreover, a serious imbalance, which leads to an excessive onerousness in performing the obligation of the contracting party, also stands against the universal concept of proportionality.22 Therefore, it is necessary for the parties that are affected by the change of circumstances to renegotiate the contract for and with the other contracting parties or to bring the contract to the judges for modification.

20 Adat (customary) Law is a law that prevails and develops in a community in a certain area. There are several notions of customary law. According to Cornelis van Vollennhoven, a customary law is a set of rules concerning behaviour for indigenous people and the Foreign East, which on the one hand has sanctions (because it is legal), and on the other hand is not codified (because of Adat). Wulansari, C., \& Gunarsa, A. (2010). Hukum adat Indonesia : Suatu pengantar. Bandung: Refika Aditama, p. 3-4

21 Kotter, J.P. (2012). Accelerate!. Harvard Business Review, 90 (11): 1

22 Hernoko, A. (2010). Hukum perjanjian asas proporsionalitas dalam kontrak komersial. Jakarta: Kencana. 285. 
Unfortunately, the discourse of Indonesian contract law reformation has not yet been addressed by the Indonesian legislators until now. There is no new Contract Law bill included in the National Legislation Program from the House of Representatives of The Republic of Indonesia (DPR RI). In contrast with the legislators, the renewal of the Indonesian contract law is one of the priority points on the agenda of the Institute of National Legal Development (BPHN). ${ }^{23}$ They argue that contract law is a significant field of law for Indonesia in the era of globalisation, especially in supporting the activities conducted in the trade sector and transactions of international business operations. After considering the urgency of renewing Indonesia's contract law, the BPHN took the initiative to start the development of national legislation at this level by drafting a new regulation. As of 2013, the team has produced an academic analysis and a bill. ${ }^{24}$ The drafters have already accepted the notion of hardship (change of circumstances) as a basis for contract adjustment in their new draft.

\section{Change of Circumstances as a Basis for Contract Modification in Dutch Law}

This section discusses the perspective of Dutch law and includes an analysis of the development of unforeseen circumstances and application of unforeseen circumstances as a basis for contract modification in case law.

\subsection{Change of Circumstances under Dutch Law}

The position in which Dutch law stands with regard to the change of circumstances is diametrically opposed to the position occupied by Indonesian law. After the 1992 transformation of the Dutch Civil Code, Dutch legislators agreed to incorporate the concept of unforeseen circumstances and formulated it explicitly in the DCC. This concept thus gives power to the judge, on demand of a party, to adapt the contract which has become excessively burdensome for contractual parties to perform, or which has become meaningless for one or both of the parties. The power to make an adaptation includes the discretion of being able to revise the main obligations. For instance, the contractual price can be reduced or raised before the court. In this provision, we can also see the interaction between contractual parties and the court in the case of the occurrence of unforeseen circumstances to formulate new contractual terms.

This section will discuss unforeseen circumstances as a basis for contract modification under Dutch law. This concept may also be deemed to provide a solution of the Indonesian law as discussed in the previous section. The Dutch Civil Code uses the term "unforeseen circumstances" to label external factors that hamper the performance of a contract (hereinafter also referred to as 'unforeseen circumstances'). The use of the phrase "unforeseen circumstances" has in due course also become widely accepted in Dutch legal practice.

The old Dutch Civil Code (hereinafter, old DCC) of 1838 was enacted in the Netherlands under a strong influence from the original French Civil Code, which rejected the idea of

$23 \mathrm{BPHN}$ is the supporting body which implements main tasks of the Ministry of Justice and Human Rights in the field of national legal development. It is subordinate to and directly responsible to the Minister of Justice and Human Rights of the Indonesian Government. For further information, Available from: www.bphn.go.id/.

24 Badan Pembinaan Hukum Nasional. (2013). Naskah Akademik Rancangan Undang Undang Hukum Kontrak, p. 3 
imprevision in the performance of a contract. ${ }^{25}$ Therefore, the similarities between Dutch and French law cannot be denied, especially in regard to dealing with change of circumstances. Because of this, the old DCC also did not contain any provision which entitled a party to rely on a change of circumstances to adapt the contract when a performance by one of the parties has become excessively burdensome.

The old Dutch Civil Code stipulated unforeseen circumstances only in the sense of impossibilities. It refers to the Article 1280 of the former DCC, which states that the debtor is liable to pay damages in the case of non-performance unless he can prove force majeure. In a similar way to the Indonesian Civil Code, this Article was mainly related to payment of compensation. Moreover, in the case of duty to deliver a particular object, it refers to Article 1480 of the old DCC. This Article 1480 states that "where a thing certain and determined which was the purpose of an obligation perishes, may no longer be the subject matter of legal transactions between private individuals, or is lost in such a way that its existence is entirely unknown, the obligation is extinguished if the thing had perished or has been lost without the fault of the debtor, and before he was under notice of default." We can notice that the old Code only provided relief for the debtor in cases of impossibility caused by force majeure. For this reason, if it was impossible to perform the obligation due to force majeure, the duty to perform ceased as well, the debtor was released from any obligation to pay damages, and the contract was discharged. If, however, performance was possible, there was no force majeure.

The decisive reason that Dutch law eventually admitted unforeseen circumstances in its new Civil Code was initially triggered by the outbreak of World War I. Following the initial beginning of the twentieth century, the war resulted in great economic turbulence (among other events, a sudden rush on banks, hoarding of coinage, and general disruption caused by the financial system). ${ }^{26}$ The conditions of war at that time were still insufficient to convince the Supreme Court to change its mind, and the Supreme Court was reluctant to allow the debtor to be released from its obligation easily, and often rejected the defence of force majeure. ${ }^{27}$ The war, in turn, inspired a legal debate whether the notion of impossibility should include not only factual (objective) impossibility but also personal (subjective) impossibility. ${ }^{28}$ The latter suggested that the debtor was exempted for non-performance if he had performed everything within his efforts to accomplish the contract, but had failed due to external factors for which he had no liability.

Later on, there was no longer any hesitation regarding the existence of unforeseen circumstances based on reasonableness and fairness in Dutch law. Van Boom reflected that the Great War was indeed the first rigorous test of the contract law framework of the 1838 Dutch Civil Code. This test showed that the theoretical structure of

25 This code was by and large a continuation of the 1804 Code Napoléon, which had been in force in the Dutch territories since the French annexation of the Netherlands in 1810. See Warendorf, Thomas, Warendorf, H.C.S., Thomas, Richard, \& Koninkrijk der Nederlanden. (2013). The civil code of the Netherlands (2nd rev. and enlarged ed.]. ed.). Alphen aan den Rijn: Kluwer Law International, p. 8

26 The Kingdom of the Netherlands tried frantically to maintain a position of armed neutrality between the Central Powers and the Entete Forces. Further see Van Boom, W. (2014). The Great War and Dutch Contract Law: Resistance, Responsiveness and Neutrality. Comparative Legal History, 2(2): 304

27 HR, 18 January 1926, NJ 1926, 203, WPNR 1926, no 2945, 270 (Stork v NV Haarlemsche Katoenmaatschappij (Sarong)); HR, 19 March 1926, NJ 1926, 441 (NV Textielfabriek 'Holland' v NV Tatersall \& Holdworth Machinefabrieken en Magazijnen 'De Globe' \& de Engelsche Vennootschap van Koophandel Buterworth \& Dickinson Ltd the Burnley, England).

28 Van Boom, W. op.cit. 315. 
impossibility (force majeure) was flawed in substance. ${ }^{29}$ Subsequently, the concept of subjective impossibility emerged as a potential excuse for non-performance, yet it was not satisfying and uncertain in practice. The likelihood in commercial contracts, especially in fungible goods contracts, usually centred on the extent of the debtor's motivation to dedicate his efforts and resources to certain areas of the contractual performance. The subjective impossibility doctrine did not give a reasonable justification for the fact that impecuniosity did not constitute a proper case of force majeure. In the lower courts ${ }^{30}$ as well as in academic writing, ${ }^{31}$ opinions were voiced that stood in favour of the acceptance of 'subjective impossibility' due to the ongoing war situation as a justifiable ground for non-performance, that may be a basis for the modification of the contract. In due course the concept on unforeseen circumstances as a separate doctrine of contract law began to be seriously drafted and was finally injected into the new Dutch Civil Code in the form of Article 6:258.

\subsection{Judicial Modification under Dutch Law}

Dutch contract law within the new Dutch Civil Code begins from the notion of the sanctity of a contract as stipulated in Article 6:213 paragraph 1: "A contract within the meaning of this Title is a multilateral juridical act whereby one or more parties assume an obligation towards one or more other parties." Nevertheless, in some cases, the assessed future circumstances and comprehensive coverage of these stipulations in the contract may go beyond reasonable effort and prediction on the part of the parties. In this case, Dutch contract law has provided a deviation from the pacta sunt servanda principle.

The current law grants the possibility of modifying a valid contract by means of intervention from the court in the occurrence of a change of circumstances. Dutch legislators seemed to choose a middle-ground solution in the occurrence of unforeseen circumstances in the new Dutch Civil Code. The relevant provisions related to the notion of unforeseen circumstances in the Dutch Civil Code are Article 6:258, 6:259 and 6:260. These Articles are systematically formulated in Book 6 of the Dutch Civil Code, which focuses on obligations, and under Title 5 on Agreements in General, particularly in the section 'consequences of agreements'. Based on its position within the general rules, the provision shall apply to all nominated contracts. For instance, it applies to sale contracts, gift contracts, lease agreements, agency contracts, mandate contracts, subcontracts, deposit contracts, employment contracts, surety ship contracts, construction contracts, partnership contracts, insurance contracts, and transportation contracts. Although statutory texts are not denominated, the legal concept embodied by the aforementioned Articles is commonly referred to as "unforeseen circumstances". 32

29 Ibid., at 323.

30 An argument that an increasing price 20-25 per cent was sufficient to accept Force Majeure in Rechtbank Den Bosch, 26 March 1915, NJ 1916, 439 (Firma H Van Roosmalen en Zoon v Firma Chr Fles); Gerechtshof Den Haag, 8 December 1916, W 10129 (Engel v Coöperative Inkoopsvereeniging van Roomsch Katholieke brood-, koek- en banketbakkerspatroons St Hubertus).

31 According to eminent scholars such as Meijers and Scholten, the fluctuation of price was of a systemic nature and threatened the livelihood of an entire class of debtors, on which basis legislative or judicial intervention was considered appropriate. See Van Boom, W. op.cit. 318.

32 Hondius, E., \& Grigoleit, H., op.cit . 70. 
Given the Articles 6:258, 6:259 and 6:260 of the DCC above, Article 6:258 is the most substantial of the three provisions when discussing the topic of unforeseen circumstances as a foundation for the process of contract modification. Article 6:258 of the Dutch Civil Code states: 33

(1) Upon the demand of one of the parties, the court may modify the effects of a contract, or it may set it aside, in whole or in part, on the basis of unforeseen circumstances of such a nature that the other party, according to standards of reasonableness and fairness, may not expect the contract to be maintained in unmodified form. The modification or setting aside may be given retroactive effect.

(2) The modification or the setting aside shall not be pronounced to the extent that it is common ground that the person invoking the circumstances should be accountable for them or if it follows from the nature of the contract.

(3) For the purposes of this article, a party to whom a contractual right or obligation has been transmitted, is treated as a contracting party.

It is evident that the Art. 6:258 of the DCC above offers a chance to a contracting party (including a person to whom a contractual right and obligation have been transferred) in an excessively onerous situation to request the modification of the contract before the court. In addition, the Article specifically says that the amendment of a contract shall be made "on the basis of unforeseen circumstances of such a nature that the other party, according to standards of reasonableness and fairness, may not expect the contract to be maintained in unmodified form". This means that the notion of "unforeseeability of circumstances" and the "standard of reasonableness and fairness" are crucial in the Article 6:258 DCC.

In applying unforeseen circumstances, Art. 6:258 has two important criteria. The first criterion covers the fact that the circumstances must have been "unforeseen". That is to say, the parties would have all the time that is necessary to provide for all conceivable circumstances, and they would know what matters. The second criterion covers the fact that the circumstances must be such that the other party may not expect the agreement to remain unmodified according to the standard of reasonableness and fairness. Here the aforementioned specification of the nature of the contract and common opinion applies.

In addressing the first criterion, namely unforeseeability of circumstances, there are two conditions that shall be noted to determine the unforeseen nature of the event. ${ }^{34}$ The first condition is the relevancy of circumstances that relates to the future, and which contrasts with the moment of entering into a contract. If the parties have already realised or should have known about upcoming events which may lead them to change the contractual balance, it shall be assumed that they have distributed relevant risks in the contract. The second condition notes that the circumstances have not become part of the contractual provisions. The parties shall not provide specific circumstances in their contract, either explicitly or implicitly. This element (viz. unforeseeability of circumstances) is essential with regard to the successful claim of unforeseen circumstances since it is an area where parties may intervene within the ambit of Article 6:258 of the Dutch Civil Code.

\footnotetext{
33 Articles cited from Dutch Civil Code are taken from the translation of Warendorf, Thomas, Warendorf, H.C.S., Thomas, Richard, \& Koninkrijk der Nederlanden. (2013). The civil code of the Netherlands (2nd rev. and enlarged ed.]. ed.). Alphen aan den Rijn: Kluwer Law International.

34 Hondius, E., \& Grigoleit, H., op.cit . 72.
} 
With regard to the second criteria, the idea of reasonableness and fairness plays an important role. The judge shall carefully take into account the notions of reasonableness and fairness when examining the claim of unforeseen circumstances. Since Art. 6:258 DCC openly refers to reasonableness and fairness as a joint measure for its implementation, the provision of unforeseen circumstances are considered as lex specialis of the broader principle of reasonableness and fairness. In the Dutch Civil Code, it is clearly stated that reasonableness and fairness are the standards by which to oversee the contract. When a certain rule from a contract or from the Code itself is unacceptable according to the criteria of good faith and fair dealing, this rule is simply not binding to the circumstances. As a result, the preliminary outcome is overruled. 35 This reasonableness and fairness principle places power and responsibility in the hands of the judges, who after all is the authority who decides whether the original outcome is unacceptable or not. Reasonableness and fairness under the Dutch Civil Code are reflected in Article 6:2, as it is stated as follows:

An obligee and obligor must, as between themselves, act in accordance with the requirements of reasonableness and fairness.

A rule binding upon them by virtue of law, usage or a juridical act does not apply to the extent that, in the given circumstances, this would be unacceptable according to standards of reasonableness and fairness.

In addition to this provision, reasonableness and fairness may serve as an additional supplementation when the interpretation of the contract does not provide the necessary answer, as stated in Article 6:248 of the Dutch Civil Code: 36

(1) A contract not only has the juridical effects agreed to by the parties, but also those which, according to the nature of the contract, apply by virtue of law, usage or the requirements of reasonableness and fairness.

(2) A rule binding upon the parties as a result of the contract does not apply to the extent that, in the given circumstances, this would be unacceptable according to standards of reasonableness and fairness.

The three supplementation sources (namely law, usage or the requirements of reasonableness and fairness) do not come in a fixed order or hierarchy, and this again leaves the judge to decide which of the three is the most appropriate for the situations of the case. ${ }^{37}$ Furthermore, in many other countries, this concept is indeterminate and relative, and enforcement of such a principle heavily depends on the judges. In facing such a problem, Dutch law has created a guide for the judges in the shape of Art. 3:12 of the Dutch Civil Code. It states that in determining what reasonableness and fairness requires, one must take into account generally accepted principles of law, current juridical views in the Netherlands and the societal and private interests involved in the case. It is apparent that the New Dutch Civil Code gives much greater discretion to the court on the reasonableness and fairness principle. This condition is a field where the

35 Nieuwenhuis, H. \& Hijma, J. (2014). Modern Codified Contract Law: The Dutch Example Text and Cases, p. 26.

36 Article 6:248 paragraph 1 DCC states: "A contract not only has the juridical effects agreed to by the parties, but also those which, according to the nature of the contract, apply by virtue of law, usage or the requirements of reasonableness and fairness."

37 Hijma, J. "The role of the court and of the parties in adapting a contract to unforeseen circumstances", on Castermans, Bezemer, Castermans, A.G., \& Bezemer, C.H. (2012). Foreseen and unforeseen circumstances (BWKJ, 27). Deventer: Kluwer, p. 4 
court will exercise its discretion: it will investigate what parties of similar expertise, and in similar circumstances, would have agreed. 38

As a matter of fact, Article 6:258 of the Dutch Civil Code is a mandatory provision of the Dutch Civil Code that cannot be excluded by the parties in their agreement, and, by law, the aggrieved party may propose a modification of the contract to the judges to a certain extent. ${ }^{39}$ However, the activation of the Article may be limited by addressing as many as possible future circumstances in the context of their agreement. Through this means, if the parties have agreed on future circumstances and risk allocation before concluding the contract, and a change of circumstances takes place, each party cannot invoke Art. 6:258 of the Dutch Civil Code because the scope of the element 'unforeseen', as required by Art. 6:258, is lacking due to the foreseeability of the circumstances.

It is also important to note that, under a case law, the provision of unforeseen circumstances in Article 6:258 of the DCC should be applied restrictively, since reasonableness and fairness require a commitment primarily to the contractual wording. On the one hand, it may benefit one party, but on the other hand, it also clearly harms another party. Therefore, it is understandable that the Dutch legislature has explained, and the Dutch Supreme Court (Hoge Raad) has emphasised, 40 that Art. 6:258 of the DCC should be applied hesitantly (or with due care). The judiciary shall adopt a reserved attitude towards the alteration of contracts. This condition then makes it difficult that the requirements of a favourable claim of unforeseen circumstances are fulfilled in practice. ${ }^{41}$ Nonetheless, a contract is a product between the parties, and it binds them together in a legal relationship (pacta sun servanda principle). The court should respect the contract made by the party because interference in a contract can be considered to be an arbitrary action, especially if it is related to an economic issue of the obligations.

\section{Conclusion}

It has been explained in the previous sections that Indonesian and Dutch legal systems have different approaches regarding the recognition of the change of circumstances in their legal systems. On the one hand, Dutch law recognises unexpected circumstances other than impossibility (force majeure) as unforeseen circumstances. On the other hand, change of circumstances in the sense of excessive onerousness is not generally accepted by the Indonesian Civil Code which have been studied in this article, but it can be argued as being available as subjective force majeure in Indonesian law doctrines and decisions.

To be more detail, the existence of explicit laws stipulating the change of circumstances in the sense of excessive onerousness seems to be very different in the civil code in the new Dutch Civil Code and the Indonesian Civil Code. The Dutch Civil Code has obviously accommodated unforeseen circumstances in Article 6:258, while the Indonesian Civil Code still does not explicitly address such an issue. Indonesian Law only goes so far as to provide Articles 1244 and 1245 ICC in which the situation where it is impossible to perform has occurred (force majeure). Nevertheless, the interpretation of the force majeure doctrine (Article 1244 and 1245 of the ICC) by the judiciary body and by

38 Hondius, E., \& Grigoleit, H., op.cit. 71.

39 Art. 6:250 of the Dutch Civil Code states: "A contract may derogate from the following articles of this Section, with the exception of Articles 251 (3), 252 (2), insofar as the requirement of a notarial instrument is concerned, and paragraph 3, 253 (1), 257, 258, 259 and 260."

40 Hoge Raad 20 February 1998, NJ 1998, 493.

41 Hoge Raad 19 November 1993, NJ 1994, 156 (Campina v. Van Jole) and Hoge Raad 20 February 1998, NJ 1998, 493 (Briljant Schuders v. ABP). 
legal scholars exceeds the notion of the impossibility to perform. Most legal jurists in Indonesia have stated that force majeure can be stretched to the situation which falls outside impossibility of the so-called subjective (relative) force majeure. This broad interpretation has been confirmed by the Indonesian (Supreme Court) in several cases. At this point, Indonesian law and Dutch law seem to be similar in their respective scope of unforeseen circumstances.

Regarding judicial intervention in modifying the contract, Dutch contract law recognises the amendment to a contract as one of the available remedies in cases of unforeseen circumstances. If parties have acted under the principle of reasonableness and fairness, either party may request a modification of a contract to the new situation before the court. The Dutch Civil Code grants discretion to the court in order to achieve a just outcome for both parties. On the other hand, court modification is not provided as a general remedy in Indonesia. However, an adaptation can be argued to be an available remedy for the parties on the basis of the good faith principle in Indonesian law, but in practice, the courts have been very reluctant to grant it.

In the civil law tradition, the ground in giving the court the authority to adapt the contract in the situation when the performance of the contract has been excessively burdensome is the general doctrine of good faith. It is reasonable for the parties to expect an adaptation of the contract in the occurrence of an excessively burdensome situation, given that cooperation in the context of the contractual relationship shall be grounded by good faith between parties. In the Indonesian Civil Code, although there are no provisions regarding contract modification, some cases in Indonesia are presented in such a way that the court sometimes modifies a contractual relationship under such a principle of good faith. On the other side, in Dutch law, good faith or reasonableness and fairness is already alive as a fully developed doctrine in Article 6:258 the DCC, so that, on the explicit basis of good faith, the courts may derogate specific provisions in their contracts in order to avoid an unjust situation affecting the performance of the contract.

Regarding changed in circumstances and contract modification, from the previous preceding discussion, we can note that there are differences in the available remedy for changed circumstances under Indonesian and Dutch law. Indonesian Law still uses the all-or-nothing approach of termination and rejects the concept of subjective (relative) force majeure to modify a binding contract, although in some cases the Indonesian Supreme Court has modified contracts on the basis of good faith implementation. Dutch law, on the other hand, evidently has a provision for the adjustment of contract on the basis of unforeseen circumstances in Art. 6:258 of the DCC. This jurisdiction accepts that unforeseen circumstances can be justified as a basis for adaptation of the contract, particularly in a situation where upholding the original contractual provisions is no longer possible. The Dutch remedy aims at distributing the risk between the parties and giving the judges the role of a 'moderator'.

Indonesian law has been willing to relax the circumstances that count as force majeure under the term subjective (relative) force majeure, but this development in Indonesia has not gone so far as to develop the modification of the contract by the court, where, by comparison, Dutch law in the new DCC has taken the latter step to develop. The development in the Netherlands was mainly because of the Great War, which triggered Dutch law to develop the discretionary power of the court to modify the contract. The subjective impossibility doctrine under Dutch law did not give a reasonable justification for the fact that impecuniosity did not constitute as force majeure. Although the Dutch 
Supreme Court opposed modification of contractual terms, the lower courts, as well as academic writings, counter-argued that "subjective impossibility" due to the war situation was a justifiable non-performance that may constitute a basis for modification of the contract. In contrast with the Netherlands, although Indonesia has experienced a monetary crisis in 1997-1998,42 the situation was not dire enough to trigger the same result compared to the aforementioned Dutch law history.

Following the above analysis, if we compare the reluctance given to the concept of contract modification under subjective force majeure in Indonesian law, the Dutch law approach seems rather liberal in dealing with the excessively onerous situation. Nevertheless, if we observe the fundamental criteria in Article 6:258 of the DCC that the party shall prove "... on the basis of unforeseen circumstances of such a nature that the other party, according to standards of reasonableness and fairness...", it would be quite difficult to be satisfied by the affected party in practice. ${ }^{43}$ Furthermore, the Dutch judiciary institution also heavily requires that the performance under the original contract provision must be unacceptable in light of the principles of reasonableness and fairness. ${ }^{44}$ In the end, we can see that even after a change of circumstances is considered as a ground of relief for the aggrieved party, a contract adaptation is still a highly contested remedy in Dutch law.

Given the explanation above, we may argue that the concept of contract modification is related to the idea of interpretation because the judge seeks the implicit intention of the parties in the contract. Therefore, in order to ensure that a contract exists in the events of changed circumstances, there is a justification for judicial interventions to a binding contract. In the previous discussion of Indonesian law, the judges interpreted contractual provisions in light of the good faith principle. The implementation of the good faith principle may be a solution to a civil legal system that does not have judicial modification rules in the civil code such as Indonesia. Other than that, at the time before concluding a contract, sometimes the parties are sufficiently aware of the need to adjust their relationship in the future. They sometimes then agree on indefinite wording in their contracts, such as to do something in a 'commercially reasonable time' and to use 'best efforts'. ${ }^{45}$ Although a reasonable time for taking any decision depends on the nature, purpose, and situations of such action, this represents a signal from the parties to adjust the contract in light of the future unexpected circumstances.

42 Exchange rate of Indonesian currency (Rupiah) was depreciated 80 per cent from Rp. 4,850/US dollar in 1997 to a level of around Rp. 17,000/US dollar on January 22 1998. For a further overview of Indonesian economic crisis in 1998, see Thee, K. W. (2012). Indonesia's economy since independence (ISEAS current economic affairs series. 11442568X). Singapore: Institute of Southeast Asian Studies (ISEAS), p. 109

43 Hoge Raad 19 November 1993, NJ 1994, 156 (Campina v. Van Jole) and Hoge Raad 20 February 1998, NJ 1998, 493 (Briljant Schuders v. ABP)

44 A guidance this term can be found in Article 3:12 of the DCC, which provides that reasonableness shall be determined in view of the general accepted legal principles, i.e. fundamental conceptions of law in the Netherlands and relevant social and personal interests, which are involved in a given situation.

45 Goetz, C., \& Scott, R. (1985). The Limits of Expanded Choice: An Analysis of the Interactions between Express and Implied Contract Terms. California Law Review,73(2): 317 


\section{References}

Agustina, R, Suharnoko \& Nieuwenhuis, H. (2012). Hukum perikatan (Law of obligations) (Seri unsur-unsur penyusun bangunan negara hukum. Denpasar: Pustaka Larasan. 6.

Badan Pembinaan Hukum Nasional. (2013). Naskah Akademik Rancangan Undang Undang Hukum Kontrak. 3.

French Civil Code from the translation of Prof. Georges Rouhette, Professor of Law, with the assistance of Dr Anne Rouhette-Berton, Assistant Professor of English.

Gautama, S. (1995). Indonesian business law (Cet. ke-1.. ed.). Bandung: Citra Aditya Bakti.

Gerechtshof Den Haag, 8 December 1916, W 10129 (Engel v Coöperative Inkoopsvereeniging van Roomsch Katholieke brood-, koek- en banketbakkerspatroons St Hubertus).

Goetz, C., \& Scott, R. (1985). The Limits of Expanded Choice: An Analysis of the Interactions between Express and Implied Contract Terms. California Law Review,73(2),

Hernoko, A. (2010). Hukum perjanjian asas proporsionalitas dalam kontrak komersial. Jakarta: Kencana.

Hoge Raad 19 November 1993, NJ 1994, 156 (Campina v. Van Jole) and HR 20 February 1998, NJ 1998, 493 (Briljant Schuders v. ABP).

Hoge Raad 19 November 1993, NJ 1994, 156 (Campina v. Van Jole) and HR 20 February 1998, NJ 1998, 493 (Briljant Schuders v. ABP)

Hoge Raad 20 February 1998, NJ 1998, 493.

Hoge Raad, 18 January 1926, NJ 1926, 203, WPNR 1926, no 2945, 270 (Stork v NV Haarlemsche Katoenmaatschappij (Sarong));

Hoge Raad, 19 March 1926, NJ 1926, 441 (NV Textielfabriek 'Holland' v NV Tatersall \& Holdworth Machinefabrieken en Magazijnen 'De Globe' \& de Engelsche Vennootschap van Koophandel Buterworth \& Dickinson Ltd the Burnley, England).

Hondius, E., \& Grigoleit, H. (2011). Unexpected Circumstances in European Contract Law. Cambridge: Cambridge University Press.

Horn, N. (1985). Adaptation and renegotiation of contracts in international trade and finance (Studies in transnational economic law; vol. 3. 821849247). Deventer: Kluwer Law and Taxation.

Indonesian Civil Code (Kitab Undang-Undang Hukum Perdata Indonesia)

Indonesian Supreme Court Decision No. 1787 K / PDT / 2005 (PT. Pertamina (Persero) v. PT. Wahana Seno Utama).

Indonesian Supreme Court Decision No. 3389 K / PDT / 1984 (R.P. Adianto Notonindito v. PT Tirta Santika).

Indonesian Supreme Court Decision No.15 K / Sip. / 1957 (NV Handel Maatschappij L'Auto v. G.G. Jordan).

Hijma, J. The role of the court and of the parties in adapting a contract to unforeseen circumstances, on Castermans, Bezemer, Castermans, A.G., \& Bezemer, C.H. 
(2012). Foreseen and unforeseen circumstances (BWKJ, 27). Deventer: Kluwer.

Kotter, J.P. (2012). Accelerate!. Harvard Business Review 90 (11).

Momberg Uribe, R. (2011). The effect of a change of circumstances on the binding force of contracts: Comparative perspectives (Ius Commune reeks; 94 114765189). Cambridge [etc.]: Intersentia.

Nieuwenhuis, H. \& Hijma, J. (2014). Modern Codified Contract Law: The Dutch Example Text and Cases.

Rahmanata, A., \& Wirana, A. (2009). Civil code for Indonesia: Burgelijk wetboek, proclaimed by the publication of April 301847 S. No. 23. Jakarta: Lembaga Penerbit Fakultas Ekonomi Universitas Indonesia.

Rechtbank Den Bosch, 26 March 1915, NJ 1916, 439 (Firma H Van Roosmalen en Zoon v Firma Chr Fles)

Soebekti, R. (2002). Hukum perjanjian (Cet.ke-19. ed.). Jakarta: Intermasa.

Soemadipradja, R. (2010). Penjelasan hukum tentang keadaan memaksa. Jakarta: Nasional Legal Reform Program (NLRP).

Soerodjo, I., (2016). the Development of Indonesian Civil Law, Scientific Research Journal (SCIRJ). Vol. IV Issue IX.

Sofwan, S. (1980). Hukum perutangan. Yogyakarta: Seksi Hukum Perdata Fakultas Hukum, Universitas Gadjah Mada. 20.

Thee, K. W. (2012). Indonesia's economy since independence (ISEAS current economic affairs series. 11442568X). Singapore: Institute of Southeast Asian Studies (ISEAS).

Van Boom, W. (2014). The Great War and Dutch Contract Law: Resistance, Responsiveness and Neutrality. Comparative Legal History, 2(2).

Warendorf, Thomas, Warendorf, H.C.S., Thomas, Richard, \& Koninkrijk der Nederlanden. (2013). The civil code of the Netherlands (2nd rev. and enlarged ed.]. ed.). Alphen aan den Rijn: Kluwer Law International.

Wulansari, C., \& Gunarsa, A. (2010). Hukum adat Indonesia: Suatu Pengantar. Bandung: Refika Aditama.

\section{Conflict of Interest Statement:}

The author(s) declares that the research was conducted in the absence of any commercial or financial relationships that could be construed as a potential conflict of interest.

Copyright @ 2019 HALREV. All rights reserved. 